\title{
PENGARUH GENDER SEBAGAI PEMODERASI PENGEMBANGAN MODEL PERILAKU KONSUMEN HIJAU DI INDONESIA
}

\author{
M.F. Shellyana Junaedi ${ }^{1}$ \\ Fakultas Ekonomi Universitas Atma Jaya Yogyakarta
}

\begin{abstract}
This study examined the model development causal that can predict the green consumer behavior on organic food as green product. This study tested the influence of values orientation on environmental consciousness. This study also explained the effect of ecological knowledge, ecological affect, premium price and environment consciousness on green purchase intention. The role of gender as moderating variables on the causal model development. The analysis of 723 respondents all of those are people who influence and purchase their daily food. The result, based on path analysis using multi group structural equation modeling, indicated that the model tested had an acceptable fit. The idea implied in this research will be much help in resolving problem and decision making, connected to reinforce the green purchasing.
\end{abstract}

Keywords: green consumer, attitude, behavior, organic food, gender

\section{PENDAHULUAN}

Berkaitan dengan pemasaran lingkungan, saat ini tren keamanan pangan (food safety) menjadi isu sensitif dalam industri pangan. Isu bahan pangan yang aman ini telah meningkatkan kesadaran masyarakat pada krisis lingkungan yang menuntut setiap orang untuk memiliki gaya hidup sehat dan hemat (Junaedi, 2005). Perbaikan mutu kehidupan dan gaya hidup sehat telah mendorong masyarakat di berbagai Negara dan mendorong gerakan gaya hidup sehat dengan tema global kembali ke alam atau back to nature. Gerakan ini didasari bahwa segala sesuatu yang berasal dari alam adalah baik dan berguna serta menjamin adanya keseimbangan.

Konsumen yang memiliki kesadaran lingkungan sering juga disebut green orientation yang pada masa mendatang diprediksikan akan meningkat. Konsumen yang memiliki kesadaran tinggi terhadap lingkungan akan memilih produk-produk yang ramah lingkungan walaupun harganya relatif lebih mahal (Vlosky et al.,1999; Laroche et al., 2001).

Beberapa studi perilaku konsumen berupaya untuk mengidentifikasi karakteristik konsumen yang berwawasan lingkungan yang berkaitan dengan implikasi pemasaran (Lihat Ling-yee, 1997; Chan, 1999; Vlosky et al., 1999; Chan \& Lau, 2000; Kalafatis et al., 1999; Follows \& Jobber, 2000; Chan, 2001; Jiuan et al., 2001; Laroche et al., 2001; Fotopoulos \& Krystallis, 2002). Studi-studi tersebut mencoba mengeksplorasi aspek kepedulian lingkungan dan perilaku pembelian yang berwawasan lingkungan. Temuan penelitian mengindikasi bahwa terdapat kecenderungan kepedulian lingkungan yang kuat dan konsumen lebih memilih produk-produk yang ramah lingkungan (Ottman, 1994).

Pangan organik sebagai eko produk atau produk yang ramah lingkungan sesuai untuk menjelaskan kesadaran konsumen akan linkungan. Kesadaran konsumen bukan hanya ideologi saja tetapi juga permasalahan market competition yang mempengaruhi perilaku konsumen. Pengetahuan konsumen penting diketahui untuk rantai penawaran makanan secara keseluruhan dan khususnya untuk para pengecer karena isu lingkungan mempengaruhi pembelian dan keputusan nutrisional (Junaedi, 2006).

1 Staf pengajar dan peneliti Fakultas Ekonomi Universitas Atma Jaya Yogyakarta dan alumnus Program Doktor Fakultas Ekonomi Universitas Gadjah Mada Yogyakarta. 
Permasalahan lingkungan di Indonesia selama ini terdapat kecenderungan terjadi penurunan. Untuk mengatasi permasalahan tersebut dapat dilakukan dengan meningkatkan pemahaman lingkungan seluruh masyarakat yang dalam konteks penelitian ini adalah masyarakat konsumen. Oleh karena itu, studi ini lebih menekankan pada aspek lingkungan sosial yang menyangkut relasi antara manusia sebagai komunitas. Dengan pemahaman tersebut, masyarakat konsumen Indonesia akan lebih menyadari pentingnya produk-produk ramah lingkungan dan lebih rela untuk membayar dengan harga premium untuk produk-produk ini (Junaedi, 2003).

Berdasarkan permasalahan yang telah diuraikan maka studi ini secara umum bertujuan menguji hubungan antara variabel-variabel sikap dan perilaku konsumen ramah lingkungan sebagai pengembangan model penelitian dengan peran gender sebagai variabel pemoderasi model penelitian secara keseluruhan. Untuk mengkaji permasalahan lingkungan tersebut, maka studi ini akan menggunakan Multigroup Structural Equation Modelling (MSEM) untuk menguji model kausal terintegrasi secara simultan dengan pemoderasi.

Studi tentang sikap dan perilaku konsumen ramah lingkungan ini diharapkan dapat memberikan manfaat untuk mengungkap fenomena yang lebih jelas tentang hubungan antara sikap konsumen terhadap lingkungan terhadap perilaku komitmen konsumen dalam menentukan pilihannya pada pangan organik sebagai produk ramah lingkungan. Hubungan antara sikap dan perilaku konsumen ramah lingkungan dengan niat beli produk ramah lingkungan ini dimoderasi oleh peran gender konsumen. Studi tentang hubungan sikap-niat-perilaku telah banyak dilakukan sebagai kerangka konseptual sejumlah penelitian, namun belum diujikan untuk konteks memprediksi pembelian dari suatu produk spesifik yang ramah lingkungan (Follows \& Jobber, 2000).

\section{TINJAUAN LITERATUR DAN RERANGKA MODEL PENELITIAN}

Teori keperilakuan dalam penelitian pemasaran lingkungan yang digunakan setelah tahun 1990-an lebih memfokuskan pada model struktural sikap tiga komponen, yaitu kognitif, afektif dan konatif (Lihat Kalafatis et al., 1999; Chan, 1999). Ketiga komponen tersebut merupakan konstruksi model dari ilmu psikologi yang mendasari terbentuknya dimensi sikap. Hubungan antar komponen sikap tersebut telah terbukti dapat menjelaskan dan memprediksi perilaku dengan baik (Ajzen, 1988). Namun berdasarkan temuan kajian literatur empiris mengungkap adanya hubungan yang tidak konsisten antara sikap dan perilaku pada lingkungan (Martin \& Simintras, 1995), walaupun telah secara luas diteliti dengan kategori obyek penelitian, latar dan desain penelitian serta metode pengujian yang berbeda-beda.

Beberapa penelitian berupaya untuk mengidentifikasi karakteristik konsumen yang berwawasan lingkungan yang berkaitan dengan implikasi pemasaran (Lihat Ling-yee, 1997; Chan, 1999; Vlosky et al., 1999; Chan \& Lau, 2000; Kalafatis et al., 1999; Follows \& Jobber, 2000; Chan, 2001; Jiuan et al., 2001; Laroche et al., 2001; Fotopoulos \& Krystallis, 2002). Studi-studi tersebut mencoba mengeksplorasi aspek kepedulian lingkungan dan perilaku pembelian yang berwawasan lingkungan. Temuan penelitian mengindikasi bahwa terdapat kecenderungan kepedulian lingkungan yang kuat dan konsumen lebih memilih produk-produk yang ramah lingkungan (Ottman, 1995).

Meningkatnya permintaan produk-produk ramah lingkungan ini ditanggapi beberapa perusahaan dengan baik, walaupun masih banyak perusahaan yang belum mempedulikan permasalahan pemasaran lingkungan. Revolusi pemasaran hijau terjadi karena terbukti bahwa 30 sampai 40 persen degradasi lingkungan dikarenakan oleh aktivitas perilaku konsumsi rumah tangga (Chan, 1996). Hal ini menunjukkan bahwa jika konsumen memperlihatkan sikap yang positif terhadap isu-isu lingkungan maka mereka akan memiliki perilaku konsumsi yang mengarah pada kesadaran lingkungan.

Studi tentang sikap dan perilaku konsumen pada kepedulian lingkungan telah dilakukan oleh Chan (1999) di Cina. Studi tersebut menghasilkan temuan bahwa kepedulian lingkungan masyarakat Cina masih rendah walaupun mereka sangat ingin menanggulangi permasalahan-permasalahan yang berkaitan dengan lingkungan. Untuk mendukung pergerakan revolusi hijau di Cina, para pemasar dan pemerintah perlu mendorong kepedulian lingkungan dalam bentuk komitmen aktual konsumen dalam melakukan keputusan pembelian.

Dalam studi yang dilakukan Chan dan Lau (2000) dengan latar China mengindikasi bahwa pengetahuan 
ekologikal masyarakat Cina dan niat mereka untuk melakukan pembelian produk ramah lingkungan juga relatif rendah. Studi tersebut bertujuan untuk menentukan pengaruh nilai budaya, afeksi ekologikal, dan pengetahuan ekologikal terhadap perilaku pembelian hijau konsumen Cina. Nilai budaya masyarakat Cina ternyata hanya berpengaruh pada afek ekologikal namun tidak berpengaruh pada pengetahuan ekologikal mereka. Dengan menggunakan model persamaan struktural untuk mengukur signifikansi afeksi ekologikal dan pengetahuan ekologikal pada niat beli hijau dan pembelian aktual hijau menunjukkan hubungan positif yang kuat. Hasilnya menyatakan bahwa tingkat pengetahuan konsumen Cina rendah dan perilaku pembelian hijau minimal.

Selanjutnya penelitian yang dilakukan Laroche et al. (2001) lebih menekankan pada sikap dan perilaku konsumen yang bersedia membeli produk yang ramah lingkungan dengan harga premium. Namun kelemahan pengukuran yang digunakan dalam studi-studi tersebut bersifat normatif dan mengarahkan responden pada dukungannya pada tanggung jawab lingkungan.

Studi-studi pemasaran lingkungan berikut ini lebih spesifik dan relevan dalam pemilihan kategori produk dan pengembangan instrumen penelitiannya. Model konseptual yang diteliti oleh Vlosky et al. (1999) mencoba membahas tentang pengaruh persepsi, kesadaran dan harga premium yang konsumen mau membayar untuk produk hasil hutan yang memiliki sertifikasi. Studi ini lebih memfokuskan pada hubungan antara movitasi lingkungan intrinsik dan keinginan konsumen untuk membayar dengan harga premium produk kayu bersertifikasi.

Perilaku pembelian konsumen yang berwawasan lingkungan juga diteliti oleh Follows dan Jobber (2000) dengan menggunakan produk popok bayi sekali pakai yang tidak ramah lingkungan dengan popok kain tradisional yang lebih ramah lingkungan. Penelitian mereka bertujuan untuk mengembangkan model yang dapat memprediksi pembelian dari suatu jenis produk ramah lingkungan yang spesifik. Temuan penelitian menunjukkan bahwa nilai-nilai suatu produk akan berpengaruh pada sikap konsumen pada produk tersebut dan pada akhirnya akan berpengaruh pada niat dan perilaku pembelian. Konsekuensi individual yang berimplikasi personal dari pertimbangan konsumsi ditemukan sebagai hal penting dalam memprediksi niat beli seperti konsekuensi lingkungan dari suatu produk. Studi mereka ini secara empiris menguji nilai-nilai tipologi sebagai dasar untuk menjelaskan pembentukan sikap konsumen yang bertanggung jawab sosial.

Penentuan faktor-faktor determinan yang mempengaruhi niat membeli produk yang ramah lingkungan telah dilakukan Kalafatis et al. (1999) dengan menggunakan theory of planned behaviour (TPB) sebagai dasar kerangka konseptual. Teori tersebut diujikan pada dua pasar yang berbeda, yaitu Inggris dan Yunani. Temuan penelitian menunjukkan TPB dapat secara tegar memprediksi dan menjelaskan niat membeli produk ramah lingkungan. Selain itu, struktur hubungan antar-konstrakss antara dua situasi pasar yang berbeda mengindikasi adanya stabilitas TPB sebagai teori yang sesuai digunakan dalam pemasaran lingkungan.

Studi literatur menunjukkan bahwa studi-studi terdahulu tentang kesadaran lingkungan hanya sedikit yang berhasil menjelaskan landasan sosial dari perilaku konsumen yang bertanggung jawab sosial. Oleh karena itu, studi yang dilakukan Ling-yee (1997) berusaha menjelaskan peran perbedaan karakteristik demografi konsumen pada hubungan nilai-sikap-perilaku konsumen dalam mengkonsumsi produk makanan yang sehat. Peran demografik konsumen pada keterkaitan antara nilai-sikap-perilaku dalam penelitian Ling-yee (1997) sebagai pemoderasi dalam konteks konsumsi makanan sehat yang ramah lingkungan. Variabel demografi yang memoderasi adalah status gender, domisili, keterlibatan produk, dan tingkat pendapatan dari hubungan interaksi antara sikap konsumen pada lingkungan terhadap komitmen untuk berwawasan lingkungan (Ling-yee, 1997).

Temuan penelitian yang dilakukan Jiuan et al. (2001) di Singapura menjelaskan bahwa sebagian besar masyarakat Singapura menyadari adanya permasalahan lingkungan. Kesadaran lingkungan masyarakat Singapura dibentuk karena pengaruh laporan surat khabar harian yang mereka baca daripada promosi yang dilakukan perusahaan. Sikap dan perilaku masyarakat Singapura ini dipengaruhi oleh berbagai variabel demografi seperti usia, gender, kelompok etnik dan tingkat pendidikan.

Berdasar studi tentang perilaku konsumen yang berwawasan lingkungan sebelumnya, maka studi ini merupakan studi empiris pengembangan model perilaku konsumen yang ramah lingkungan dengan obyek penelitian yang spesifik pada produk tertentu, dalam konteks studi ini adalah bahan pangan organik. Instrumen 
pengukuran variabel-variabel lingkungan dalam studi ini dioperasionalisasikan sebagai sikap pada perilaku yang spesifik untuk produk bahan pangan organik dengan latar konsumen Indonesia sehingga dapat dihasilkan temuan hubungan nilai-sikap-perilaku yang konsisten. Di samping itu, dalam studi ini akan digunakan multigroup structural equation modeling (Purwanto, 2004) sebagai alat dan metode baru yang diharapkan dapat mengubah dan mengembangkan konten model perilaku konsumen yang berwawasan lingkungan dengan perbedaan gender sebagai variabel pemoderasi model penelitian secara keseluruhan.

Posisi studi perilaku konsumen yang berwawasan lingkungan ini dibandingkan dengan penelitian sebelumnya disajikan pada Tabel 1. Perbandingan studi ini merupakan sintesis dari kajian literatur penelitian tentang kepedulian lingkungan oleh peneliti-peneliti sebelumnya. Penelitian ini membahas lebih dalam berkaitan dengan variabel-variabel orientasi nilai konsumen, afek lingkungan, pengetahuan lingkungan, dan kesadaran lingkungan, harga premium dan niat beli produk ramah lingkungan. Studi ini juga mengkaji variabel demografi seperti area domisili, tingkat pendapatan, tingkat pendidikan, dan status gender sebagai variabel pemoderasi dari model penelitian secara keseluruhan. Dengan demikian, Tabel 1. menunjukkan posisi kajian penelitian pemasaran lingkungan dibandingkan dengan penelitian pemasaran lingkungan lainnya, menunjukkan keaslian penelitian dalam mengungkap solusi permasalahan penelitian pemasaran lingkungan yang sekaligus menjadi keunikan penelitian ini.

Tabel 1.

Perbandingan dengan Penelitian Sebelumnya

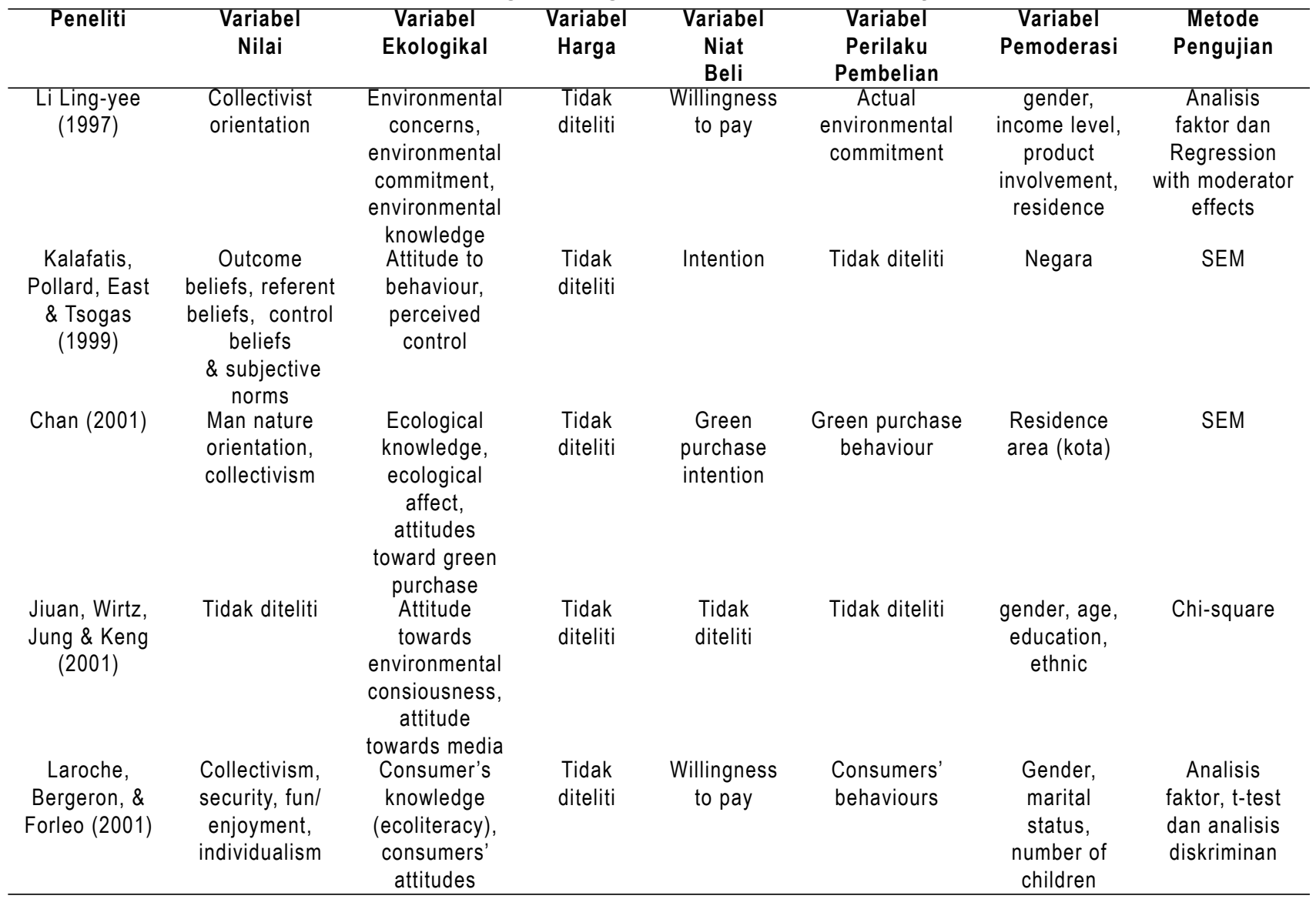




\begin{tabular}{|c|c|c|c|c|c|c|c|}
\hline $\begin{array}{l}\text { Fotopoulos } \\
\text { \& Krystallis } \\
(2002)\end{array}$ & $\begin{array}{c}\text { Greek tradition, } \\
\text { ethnocentric }\end{array}$ & Tidak diteliti & Price & $\begin{array}{l}\text { Innovative } \\
\text { behavior } \\
\text { in the food } \\
\text { purchase }\end{array}$ & Tidak diteliti & $\begin{array}{l}\text { Education, } \\
\text { area of } \\
\text { residence, } \\
\text { media use, } \\
\text { income, diet } \\
\text { habits }\end{array}$ & $\begin{array}{l}\text { ANOVA, } \\
\text { analisis } \\
\text { klaster, } \\
\text { analisis } \\
\text { diskriminan }\end{array}$ \\
\hline $\begin{array}{l}\text { Penelitian ini } \\
\text { (Shellyana) }\end{array}$ & $\begin{array}{c}\text { Values } \\
\text { orientation } \\
\text { (collectivist } \\
\text { orientation \& } \\
\text { individualist } \\
\text { orientation) }\end{array}$ & $\begin{array}{c}\text { ecological } \\
\text { Affect, } \\
\text { ecological } \\
\text { knowledge, } \\
\text { environmental } \\
\text { consiousness }\end{array}$ & $\begin{array}{c}\text { Price } \\
\text { premium }\end{array}$ & $\begin{array}{c}\text { Green } \\
\text { purchase } \\
\text { intention }\end{array}$ & $\begin{array}{c}\text { Green purchase } \\
\text { behavior }\end{array}$ & $\begin{array}{c}\text { gender, } \\
\text { Domisili, } \\
\text { income level } \\
\text { \& education } \\
\text { level }\end{array}$ & $\begin{array}{l}\text { Multigroup } \\
\text { SEM }\end{array}$ \\
\hline
\end{tabular}

Pertimbangan dalam memproses dan mengembangkan suatu teori perilaku konsumen yang komprehensif, beberapa peneliti terdahulu menggunakan penelitian dengan pendekatan psikologi sosial dalam pembentukan sikap (Ajzen \& Fishbein, 1980). Teori-teori psikologi sosial yang sering digunakan mengacu pada model nilai-harapan. Model nilai-harapan ini relevan digunakan karena menyediakan keterkaitan teoritikal antara kriteria evaluasi dan konsep kesikapan. Lebih dari empat dekade model nilai-harapan dikembangkan oleh Fishbein menjadi Theory of Reason Action (TRA), yang kemudian dikembangkan Ajzen (1988) menjadi Theory of Planned Behaviour (TPB).

Rerangka teoretikal studi ini merupakan pengembangan dari TPB karena diindikasikan bahwa TPB merupakan model penelitian telah diaplikasikan secara luas pada berbagai topik penelitian dan mengasilkan estimasi model yang tegar (robust). Oleh karena itu, tinjauan literatur studi ini berdasarkan pada rerangka konseptual hubungan antara nilai-nilai konsumen (consumer values), kognitif (cognitive), afektif (affective), niat pembelian (intention to purchase), dan perilaku (behaviour) yang berkaitan dengan kesadaran lingkungan konsumen. Gambar 1. menjelaskan rerangka hubungan antar-variabel-variabel tersebut.

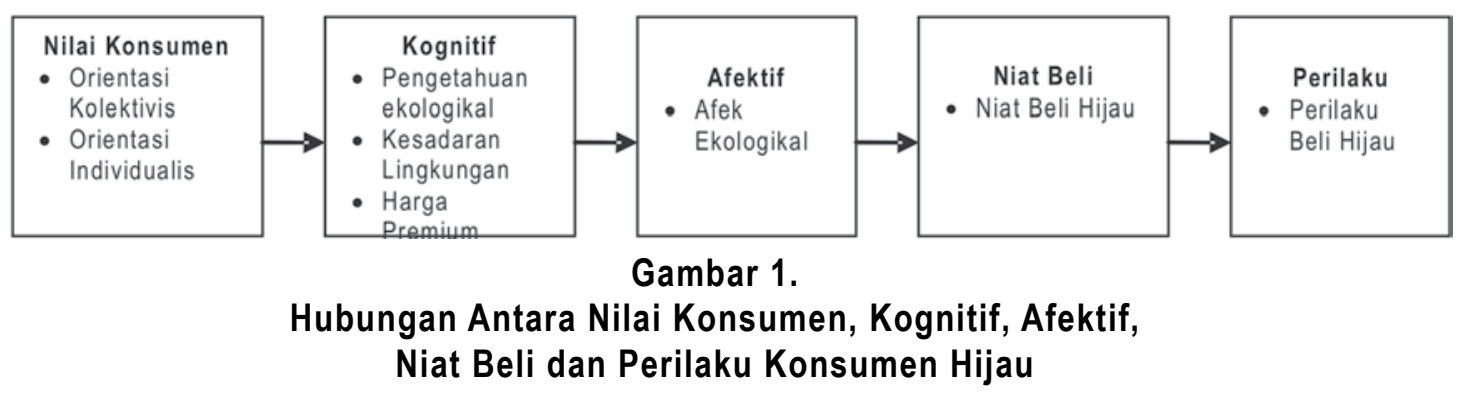

\section{Pengaruh Gender Pada Komitmen Perilaku Ramah Lingkungan}

Penelitian sikap terhadap lingkungan terdahulu berupaya untuk memetakan profil demografik konsumen secara keseluruhan. Tinjauan literatur kesadaran lingkungan mengindikasi bahwa dasar perbedaan sosial demografik ini memiliki keterbatasan dalam menjelaskan perilaku konsumen yang bertanggung jawab pada lingkungan. Kajian literatur menunjukkan bahwa kesadaran lingkungan hanya sedikit yang berhasil menjelaskan perilaku sosial konsumen yang berwawasan sosial. Studi yang dilakukan Ling-yee (1997) berupaya menjelaskan peran perbedaan karakteristik demografi konsumen pada hubungan nilai-sikap-perilaku konsumen dalam mengkonsumsi produk ramah lingkungan. Variabel yang diduga memoderasi hubungan nilai-sikap-perilaku konsumen terhadap komitmen untuk berwawasan lingkungan ini adalah status gender, domisili, keterlibatan produk, usia, kelompok etnik, tingkat pendidikan, status menikah, jumlah anak, dan akses terhadap media (Lihat Ling-yee, 1997; Straughan \& Roberts, 1999; Chan, 2001; Jiuan et al., 2001; Laroche et al., 2001; Fotopoulos \& Krystallis, 2002; Bloom \& Sevilla, 2004) 
Dengan demikian, dapat disimpulkan bahwa peran demografik dalam menentukan komitmen pembelian produk ramah lingkungan menunjukkan bahwa karakteristik demografik menjadi pemoderasi hubungan nilai-sikap-perilaku dalam konteks konsumsi makanan sehat (lihat Mathios, 1996; Ling-yee, 1997; Straughan \& Robert, 1999; Jiuan et al., 2001). Studi ini mengkaji lebih lanjut tentang peran gender dalam memoderasi hubungan nilai-sikap-perilaku mengkonsumsi produk berwawasan lingkungan.

Perkembangan peran gender menunjukkan bahwa sikap wanita lebih konsisten dibandingkan dengan pria dalam permasalahan lingkungan (Samdahl \& Robertson, 1989; Roberts \& Bacon, 1997; Prendergast \& Thompson, 1997; Laroche et al., 2001) karena wanita dalam perbedaan peran dan perkembangan sosial lebih mempertimbangkan pengaruh tindakan mereka pada orang lain (Straughan \& Robert, 1999). Wanita dalam studi tentang kesadaran lingkungan diindikasikan lebih memiliki keinginan untuk membayar lebih untuk produk-produk yang ramah lingkungan (Prendergast \& Thompson, 1997; Fotopoulos \& Krystallis, 2002). Hasil penelitian profil konsumen yang memiliki kesadaran sosial adalah wanita yang memiliki tingkat pendidikan tinggi dengan status sosial ekonomi di atas rata-rata.

Menurut Jiuan et al. (2001), feminisme berkaitan erat dengan sikap kesadaran lingkungan pada konsumen di Singapura. Pria Singapura lebih memiliki kepedulian pada permasalahan lingkungan dan mengharapkan pihak perusahaan untuk membuat solusi permasalahan lingkungan tersebut. Namun demikian, hasil temuan penelitian lingkungan yang berdasarkan perbedaan gender masih belum terjadi kesepakatan dan bersifat inkonklusif (Lingyee, 1997; Straughan \& Robert, 1999). Studi yang dilakukan oleh Samdahl dan Robertson (1989) tidak ditemukan hubungan yang signifikan bahkan beberapa menunjukkan hasil yang bertolak belakang. Penelitian Ling-yee (1997) menunjukkan bahwa pria lebih peduli terhadap lingkungan, karena pria lebih aktif mengikuti isu politik, lebih terlibat dengan isu-isu dalam masyarakat, dan memiliki tingkat pendidikan yang lebih tinggi daripada wanita. Studi Sethuraman dan Cole (1999) tentang harga premium tidak menemukan adanya pengaruh perbedaan gender dengan keinginan untuk membayar dengan harga premium untuk produk nasional.

Studi Bender dan Derby (1992) menunjukkan bahwa konsumen wanita membaca label nutrisi produk makanan lebih sering dibandingkan konsumen pria. Dalam suatu survei yang dilakukan Food Marketing Institute menemukan bahwa wanita yang tidak bekerja lebih sering membaca daftar kandungan dan informasi nutrisi dalam pilihan kebutuhan pangan. Menurut studi Michel et al. (1994), yang dikutip Mathios (1996), menghasilkan bahwa, konsumen wanita yang berpenghasilan rendah namun peduli dengan kebutuhan pangan dan informasi nutrisi memiliki pengetahuan nutrisi yang rendah. Studi pilihan produk pangan menunjukkan bahwa wanita secara signifikan mengkonsumsi makanan yang rendah kalori dibandingkan dengan pria (Ippolito \& Mathios, 1994).

Dengan demikian, ketidaksepakatan temuan hasil penelitian bahwa, wanita lebih memiliki kesadaran lingkungan dibandingkan dengan pria ini, menunjukkan bahwa perbedaan gender mempunyai kemampuan memoderasi hubungan antar-variabel penelitian model perilaku konsumen yang bertanggung jawab pada lingkungan.

Model penelitian seperti ditunjukkan pada Gambar 2. merupakan pengembangan hasil sintesis beberapa model penelitian yang telah dilakukan oleh beberapa peneliti sebelumnya (Lihat Chan, 1999; Chan \& Lau, 2000; Chan, 2001; Ling-yee, 1997; Vlosky et al., 1999). Pengembangan model ini digunakan untuk menganalisis hubungan antara variabel orientasi nilai, pengetahuan lingkungan, afek lingkungan, kesadaran lingkungan, harga premium pada komitmen melakukan pembelian pangan organik sebagai produk ramah lingkungan. 


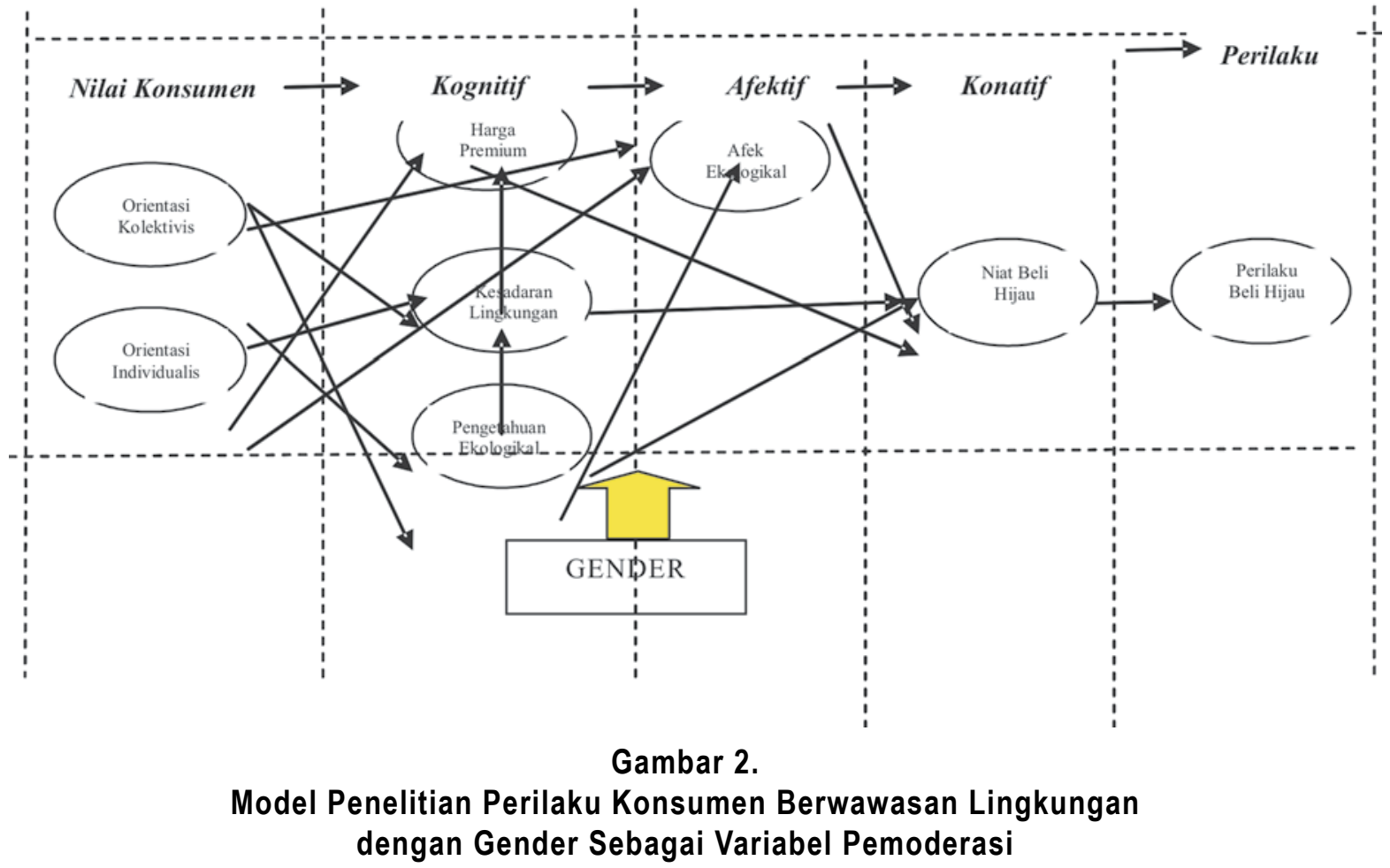

\section{METODA PENELITIAN}

\subsection{Metode Pengambilan Sampel}

Penyebaran kuesioner penelitian ini dilakukan di dua kota, yaitu Jabotabek sebagai wilayah kota metropolitan dan Daerah Istimewa Yogyakarta sebagai kota bukan metropolitan. Dasar pertimbangan penentuan kota tersebut karena Jakarta sebagai pusat ibukota negara Indonesia sebagai kota industri merupakan kota yang tingkat polusinya relatif tinggi dibandingkan dengan kota-kota di Indonesia lainnya. Selain itu, populasi masyarakat Jakarta mayoritas adalah kaum urban yang menurut studi yang dilakukan Ling-yee (1997) lebih sensitif terhadap kesadaran lingkungan. Kota metropolitan yang dimaksud dalam penelitian ini adalah Jakarta dan sekitarnya yaitu Bogor, Tangerang dan Bekasi yang merupakan perluasan wilayah metropolitan DKI Jakarta. Pemilihan Daerah Istimewa Yogyakarta berdasarkan pada pertimbangan bahwa kota tersebut merupakan kota besar yang bukan metropolitan, pusat budaya, tempat pariwisata dan kota pelajar di mana masyarakatnya cukup beragam dari berbagai suku bangsa yang bersifat multikultur. Daerah Istimewa Yogyakarta terbagi menjadi empat kabupaten, yaitu Bantul, Gunungkidul, Sleman, Kulonprogo, dan satu Kodya Yogyakarta.

Pengambilan sampel yang digunakan dalam penelitian ini adalah nonprobabilistic sampling, yaitu setiap elemen dalam populasi tidak memiliki probabilitas yang sama untuk menjadi sampel (Sekaran, 1992; Cooper \& Emory, 1995; Cooper \& Schindler, 2001). Teknik penentuan sampel secara non probabilitas yang digunakan dalam penelitian ini adalah purposive sampling. Setiap wilayah kota akan disebarkan kuesioner sebanyak 400 eksemplar. Kriteria pengambilan sampel purposif subyek penelitian ini adalah konsumen yang berperan dalam keputusan pembelian bahan pangan dan keluarganya mengolah atau memasak sendiri untuk keperluan keluarganya seharihari serta mengetahui tentang pangan organik (sayuran dan buah-buahan).

\subsection{Definisi Operasional dan Pengukuran Instrumen Penelitian}

\section{Orientasi Nilai Konsumen}

Menurut Schwartz (1994), nilai-nilai konsumen didefinisikan sebagai nilai untuk mencapai tujuan yang 
diharapkan, nilai-nilai inilah yang mengarahkan kehidupan seseorang. Nilai individu yang berpengaruh pada perilaku konsumen dibagi menjadi individualisme dan kolektivisme.

\subsection{Orientasi Individualis}

Individualisme merepresentasikan seberapa besar seseorang memfokuskan dan tergantung pada dirinya sendiri (Triandis, 1993). Kelompok ini akan bersaing dengan individu lain untuk mencapai suatu status dan lebih mementingkan kepentingannya sendiri daripada kepentingan kelompoknya. Nilai orientasi individualime menurut Laroche et al. (1999) terdiri dari tiga dimensi yaitu keinginan mencapai tujuan (achievement), pengarahan diri (selfdirection) dan pemenuhan diri (self-fulfilment) serta kebebasan (independence).

\subsection{Orientasi Kolektivis}

Kolektivisme mencerminkan konsumen yang suka bekerja sama, senang membantu orang lain, dan lebih mempertimbangkan tujuan kelompok daripada tujuan individual. Kelompok konsumen kolektivistis ini akan mendukung adanya program ramah lingkungan. Pengukuran konstraks ini mengadopsi dari kuesioner yang dikembangkan oleh Konsky et al. (2002) tentang kolektivisme yang mendasarkan pada tipologi individualiskolektivis yang dilakukan pada tiga budaya, yaitu Amerika, Indian dan Jepang.

\section{Kesadaran Lingkungan}

Kesadaran sosial konsumen dirasakan ketika seseorang berupaya untuk mempertimbangkan perilaku belinya berkaitan dengan polusi terhadap pengaruh sosial lingkungan sekitarnya. Kesadaran lingkungan sosial konsumen menurut Webster dalam Follows dan Jobber (2000) adalah konsumen yang mengingat akan akibat secara umum dari konsumsi pribadi atau usaha memanfaatkan daya beli dalam permasalahan sosial pada keputusan pembelian dengan mengevaluasi dampak dari konsumsi mereka dalam permasalahan sosial. Instrumen kesadaran lingkungan dalam penelitian ini merupakan pengembangan dari instrumen kesadaran lingkungan perilaku konsumen yang dilakukan oleh Vlosky et al. (1999).

\section{Pengetahuan Ekologikal}

Pengetahuan ekologikal yang juga disebut sebagai ekoliterasi merupakan kemampuan konsumen untuk mengidentifikasi atau mendefinisikan sejumlah simbol, konsep dan perilaku berkaitan dengan permasalahan lingkungan ekologikal (Laroche et al. 1999). Definisi pengetahuan lingkungan menurut Chan (1999) adalah seberapa besar seorang individu mengetahui isu-isu tentang lingkungan. Dalam mengembangkan skala obyektif untuk mengukur dan memahami kepedulian lingkungan, Operasionalisasi pengetahuan ekologikal dalam studi ini mengukur seberapa besar responden mengetahui tentang pengetahuan lingkungan berkaitan dengan pangan organik yang diadaptasi dari Fotopoulos dan Krystallis (2002).

\section{Afek Ekologikal}

Afek konsumen pada lingkungan merupakan tingkat emosionalitas seorang individu terhadap isu-isu lingkungan (Chan, 1999). Konsisten dengan bukti empiris yang mendukung hubungan positif antara afek ekologikal dan perilaku, mengindikasi bahwa orang dengan sedikit pengetahuan tentang lingkungan kebanyakan masih menunjukkan emosional yang tinggi (Chan \& Lau, 2000).

\section{Keinginan Untuk Membayar/Harga Premium}

Konsumen yang mau membayar lebih untuk produk-produk ramah lingkungan percaya bahwa perusahaan melaksanakan tanggung jawab sosialnya pada lingkungan (Laroche etal., 2001). Pengukuran sensitivitas harga atau the Price Sensitivity Measurement (PSM) merupakan suatu teknik yang dikembangkan sebagai suatu metodologi survai untuk pengukuran persepsi tentang harga. Teknik ini secara langsung mempertanyakan responden tentang harga. Struktur pertanyaan individual untuk responden adalah mengkualifikasi harga berdasarkan pada asumsi yang berkaitan dengan kualitas. Konstraks harga premium dalam studi ini dikembangkan dari studi Vlosky et al. (1999) dan Laroche et al. (2001) tentang keinginan seseorang dalam membayar dengan harga lebih untuk pangan organik.

\section{Niat Beli Hijau}

Niat beli hijau atau niat pembelian terhadap produk ramah lingkungan dalam studi ini adalah keinginan atau mengekspresikan niat seorang individu untuk berkomitmen pada aktivitas-aktivitas yang mendukung keramahan 
lingkungan (Chan, 1999).

\section{Perilaku Beli Produk Hijau}

Variabel perilaku pembelian aktual produk ramah lingkungan dioperasionalisasikan dengan 4 item pernyataan yang menunjukkan perilaku seseorang membeli dan mengkonsumsi pangan organik untuk kebutuhan sehari-hari sebagai ganti bahan makanan yang bukan organik. Semua pengukuran konstraks dalam penelitian ini dengan item pernyataan dengan 5 poin Skala Likert dari Sangat Tidak Setuju (STS) sampai Sangat Setuju (SS).

\section{Peran Gender Sebagai Pemoderasi}

Gender adalah pandangan masyarakat tentang perbedaan peran, fungsi, dan tanggung jawab antara laki-laki dan perempuan yang merupakan hasil konstrakssi sosial, yaitu kebiasaan yang tumbuh dan disepakati dalam masyarkat dan dapat diubah sesuai perkembangan jaman. Gender bukan kodrat atau ketentuan Tuhan, sehingga gender berkaitan dengan proses keyakinan bagaimana seharusnya laki-laki dan perempuan berperan dan bertindak sesuai dengan tata nilai, ketentuan sosial dan budaya masyarkatnya. Dalam penelitian ini gender dijelaskan berdasarkan perbedaan seks atau jenis kelamin. Seks sendiri adalah perbedaan organ biologis antara laki-laki dan perempuan, terutama pada bagian-bagian reproduksi. Seks atau jenis kelamin merupakan kodrat Tuhan sehingga tidak dapat ditukar atau diubah. Secara lebih jelas perbedaan gender dan seks atau jenis kelamin dapat dilihat dari uraian pada Tabel $2 .^{2}$.

Tabel 2.

Perbedaan Jenis Kelamin dan Gender

\begin{tabular}{ll}
\hline Jenis kelamin (seks) & \multicolumn{1}{c}{ Gender } \\
\hline - Tidak dapat diubah & Dapat berubah \\
- Tidak dapat dipertukarkan & - Dapat dipertukarkan \\
- Berlaku sepanjang zaman & - Tergantung waktu \\
- Berlaku di mana saja & - Tergantung budaya setempat \\
- Merupakan kodrat Tuhan & - Bukan kodrat Tuhan \\
\hline
\end{tabular}

Perbedaan gender merupakan karakteristik demografi yang menarik untuk diteliti berkaitan dengan isuisu lingkungan, karena perbedaan peran, keterampilan, dan sikap yang mengarah permasalahan ekologikal. Penelitian yang dilakukan di Singapura menunjukkan bahwa peran wanita dalam kehidupan menyebabkan mereka sadar akan permasalahan lingkungan (Jiuan et al., 2001). Pendapat lain yang berbeda dikemukakan oleh Ling-yee (1997) dengan studinya yang dilakukan di Hongkong mengindikasi bahwa pria lebih peduli untuk mempertahankan kualitas lingkungan. Bahkan dalam hipotesisnya disebutkan bahwa hubungan antara sikap kepedulian lingkungan dan komitmen pembelian produk ramah lingkungan lebih kuat pada pria dibandingkan wanita. Dengan demikian terdapat ketidakkonsistenan hasil temuan penelitian berdasarkan perbedaan gender berkaitan dengan isu lingkungan (Ling-yee, 1997; Straughan \& Robert, 1999).

\subsection{Pengujian Validitas dan Reliabilitas Instrumen Penelitian}

Pengujian validitas dengan menggunakan AMOS menunjukkan bahwa semua butir sahih karena nilai critical ratio $(C R)$ setiap indikator dari seluruh konstraks $\geq 2.0$ dan didukung kriteria goodness of fit yang baik. Pengujian reliabilitas untuk mengukur konsistensi dari instrumen penelitian diukur dengan menggunakan koefisien cronbach alpha dari hasil analisis faktor dan confirmatory factor analysis. Hasil pengujian reliabilitas penelitian ini secara keseluruhan dapat dikatakan bahwa instrumen penelitian ini handal (reliabel) karena nilai koefisien $\alpha$ seluruh konstraks melebihi 0.7. (Sekaran, 1992). Hasil pengujian validitas dan reliabilitas disajikan pada Tabel 3.

2 Keterangan lebih lanjut dapat dilihat pada http://hqweb01.bkkbn.go.id/hqweb/pria/artikel0121.html (diakses pada tanggal 21 Juni 2005). 
Tabel 3.

Hasil Reliabilitas Penelitian ( $=728$ )

\begin{tabular}{lcc}
\hline \multicolumn{1}{c}{ Keterangan } & $\begin{array}{c}\text { Jumlah Item yang } \\
\text { Dipertahankan }\end{array}$ & $\begin{array}{c}\text { Composite } \\
\text { Reliability }(\alpha)\end{array}$ \\
\hline Orientasi Individualistik & 13 & 0.89999 \\
Orientasi Kolektivistik & 16 & 0.89896 \\
Afek Ekologikal & 5 & 0.83079 \\
Harga Premium & 6 & 0.78137 \\
Pengetahuan Ekologikal & 12 & 0.92274 \\
Kesadaran Lingkungan & 12 & 0.89874 \\
Niat Beli Hijau & 5 & 0.85736 \\
Perilaku Beli Hijau & 4 & 0.86116
\end{tabular}

Sebelum analisis data dengan persamaan model struktural dilakukan evaluasi asumsi-asumsi persamaan model struktural. Evaluasi asumsi tersebut menunjukkan terdapat data terpencil multivariat. Observasi data penelitian yang nilai Mahalanobis distance-nya lebih besar dari 26.125, ternyata terdapat 5 observasi yang harus dikeluarkan dari perhitungan karena merupakan data terpencil multivariat. Dengan demikian, data yang dapat dianalisis dengan persamaan model struktural sebanyak 723 responden.

\section{HASIL ANALISIS DAN PEMBAHASAN}

\subsection{Profil Karakteristik Responden Penelitian}

Karakteristik responden memberikan gambaran tentang pengambil keputusan pembelian bahan pangan keluarga adalah wanita (82.1\%) dengan usia rata-rata 34.88 tahun. Responden yang telah menikah sebagian besar memiliki anak berusia kurang dari 12 tahun sebanyak 495 (68\%). Berdasar hasil temuan profil karakteristik responden penelitian ini mengindikasi bahwa pengambil keputusan pembelian bahan makan keluarga adalah ibu rumah tangga. Temuan ini mendukung studi yang dilakukan Davies et al. (1995), bahwa segmen wanita berusia 3049 tahun yang memiliki anak representatif untuk konsumsi produk hijau pada masa mendatang karena konsumen memiliki gaya hidup yang berorientasi pada kesehatan keluarganya terutama anaknya.

Hasil penelitian ini menunjukkan bahwa ada kecenderungan bahwa perbedaan jenis kelamin menunjukkan hasil bahwa pria cenderung berpendidikan lebih tinggi dibandingkan dengan wanita $(p=0.000)$, namun tingkat pendapatan pria tidak selalu lebih tinggi daripada tingkat pendapatan wanita $(p=0.714)$. Hasil tabulasi silang mendapatkan bahwa tingkat pendidikan yang semakin tinggi akan cenderung meningkatkan pendapatan $(\mathrm{p}=0.000)$. Secara lengkap karakteristik responden penelitian seperti pada Tabel 4.

Tabel 4.

Karakteristik Responden Penelitian ( $\mathrm{N}=728$ )

\begin{tabular}{|c|c|c|}
\hline Keterangan & Jumlah Responden & Persentase \\
\hline Wanita & 598 & 82.1 \\
\hline Pria & 130 & 17.9 \\
\hline SLTP/SMU & 227 & 31.2 \\
\hline Diploma & 135 & 18.5 \\
\hline Sarjana & 307 & 42.2 \\
\hline Pascasarjana & 59 & 8.1 \\
\hline
\end{tabular}




\begin{tabular}{lcc}
\hline Tingkat Pendapatan Keluarga/bulan: & 340 & \\
- $\quad$ Rp 3.000.000 & 347 & 46.7 \\
- Rp 3.001.000 - Rp 6.000.000 & 237 & 32.6 \\
- Rp 6.001.000 - Rp 9.000.000 & 96 & 13.2 \\
- Rp 9.001.000 - Rp 12.000.000 & 35 & 4.8 \\
- Rp 12.001.000 - Rp 15.000.000 & 9 & 1.2 \\
- >Rp 15.000.000 & 11 & 1.5 \\
Status: & 659 & \\
- Menikah & 52 & 90.5 \\
- Belum Menikah & 17 & 7.1 \\
- Janda/Duda & 77 & 2.3 \\
Belum Memiliki Anak & 317 & 10 \\
Anak Balita & 342 & 43.5 \\
Anak 5-12 tahun & 182 & 25 \\
Anak > 12 tahun & & 27 \\
\hline
\end{tabular}

Konsumsi berbagai media menurut Fotopoulos dan Krystallis (2002) diduga berpengaruh terhadap motif pembelian produk-produk yang bertanggung jawab pada lingkungan. Hal ini disebabkan oleh makin tinggi seseorang mengakses atau mengkonsumsi media tertentu akan menambah pengetahuan ekologikal seseorang sehingga konsumen lebih memiliki kesadaran pada lingkungan dan memiliki komitmen untuk membeli produk pangan organik.

Lingkungan media yang menjadi sumber informasi konsumen juga dapat membentuk segmen pasar yang hendak dipilih menjadi target (Haley, 1995). Informasi yang diperoleh konsumen akan mempengaruhi pemahaman pengetahuan ekologikal konsumen. Sumber informasi ini didapatkan seseorang dari berbagai sumber media, misalnya televisi, surat khabar, majalah, tabloid dan artikel ilmiah. Informasi tentang lingkungan dapat juga diperoleh dari teman, keluarga, dokter, ahli kesehatan atau secara formal dari promosi perusahaan. Dalam pemilihan media pada kenyataannya juga dapat mengindikasi karakteristik demografi dari segmen konsumen yang dipilih sebagai konsumen yang memiliki kepedulian dan kesadaran terhadap lingkungan.

Temuan penelitian ini mengungkap bahwa konsumen wanita lebih sering mendapatkan informasi dari keluarganya daripada konsumen pria. Konsumen yang tinggal di kota metropolitan dan bukan metropolitan mendapatkan informasi yang berbeda dari media televisi dan ahli kesehatan. Seseorang dari golongan menengah atas lebih sering belanja ke pasar swalayan sehingga informasi pangan organik konsumen dapatkan dari pasar swalayan dan media televisi. Ternyata perbedaan tingkat pendidikan dalam mendapatkan informasi yang berbeda tentang pangan organik berdasarkan sumber informasi media cetak, keluarga, ahli kesehatan, artikel ilmiah, dan pasar swalayan. Berbagai perbedaan variabel pemoderasi menunjukkan bahwa komunikasi formal dari promosi perusahaan tidak berbeda signifikan dalam memberikan informasi tentang pangan organik karena diakui konsumen jarang dilakukan.

Selain frekuensi mengkonsumsi media yang ada, sumber informasi yang didapatkan seorang konsumen juga dapat berpengaruh terhadap pengetahuan ekologikal dan afek ekologikal seseorang untuk lebih memiliki kepedulian terhadap lingkungannya. Informasi tersebut didapatkan seseorang dari sumber media, teman atau referensi, keluarga, dokter ataupun ahli kesehatan, artikel ilmiah, atau didapatkan dari promosi perusahaan yang memasarkan produk bahan pangan organik.

Temuan lain penelitian ini, menunjukkan bahwa untuk memenuhi kebutuhan konsumsi makanan sehariharinya responden yang berbelanja di supermarket sebesar 686 responden (94.2\%) tetapi juga di pasar-pasar tradisional 497 responden (68.3\%), warung di dekat rumah 300 responden (41.2\%), dan pedagang keliling 219 responden (30.1\%). Hampir setengah jumlah responden, yaitu sebesar 304 responden (41.8\%) melakukan belanja 
di supermarket setiap bulan sekali dan 225 responden (30.9\%) dua minggu sekali.

Hasil penelitian ini menunjukkan konsumen sering melakukan pembelian bahan makanan alami untuk diolah sendiri menjadi makanan sehari-hari. Namun dari temuan yang ada 127 responden (17.4\%) tidak pernah melakukan pembelian bahan pangan organik di supermarket, jadi hanya 601 responden (82.4\%) saja yang pernah melakukan pembelian bahan pangan organik. Dengan demikian, menurut Fotopoulos dan Krystallis (2002) berarti yang termasuk dalam karakteristik pembeli yang sadar lingkungan (aware buyers) sebanyak $82.4 \%$ dan yang termasuk dalam konsumen yang sadar pada lingkungan tetapi tidak membeli produk organik (aware non-buyers of organic product) sebesar 127 responden (17.4\%). Keputusan pembelian bahan makanan konsumen untuk keperluan keluarga sehari-hari lebih dari setengah responden menyatakan dipengaruhi oleh pasangan mereka, yaitu sebesar 464 responden (63.7\%).

\subsection{Hasil Pengujian Perbedaan Gender Pada Variabel Penelitian}

Sebelum pengujian hipotesis bahwa perbedaan jenis kelamin menjadi variabel pemoderasi dalam model penelitian dengan menggunakan persamaan model struktural, dilakukan pengujian perbedaan gender terhadap masing-masing setiap variabel penelitan dalam model secara parsial. Pengujian beda rata-rata kelompok sampel pria dan wanita ini bermanfaat untuk memberikan gambaran perbandingan perbedaan persepsi antara pria dan wanita pada variabel penelitian dalam model, yaitu orientasi individualis, orientasi kolektivis, afek ekologikal, harga premium, pengetahuan ekologikal, kesadaran lingkungan, niat beli hijau dan perilaku beli hijau. Secara lebih rinci disajikan pada Tabel 5.

Tabel 5.

\begin{tabular}{|c|c|c|c|c|}
\hline Keterangan & Kelompok & Mean & Uji t & Signifikansi \\
\hline Orientasi Individualistik & $\begin{array}{l}\text { Pria }(\mathrm{N}=130) \\
\text { Wanita } \\
(\mathrm{N}=593)\end{array}$ & $\begin{array}{l}2.3759 \\
2.2415\end{array}$ & 3.117 & $0.002^{* *}$ \\
\hline Orientasi Kolektivistik & $\begin{array}{l}\text { Pria } \\
\text { Wanita }\end{array}$ & $\begin{array}{l}4.8936 \\
4.9247\end{array}$ & -0.538 & 0.591 \\
\hline Afek Ekologikal & $\begin{array}{l}\text { Pria } \\
\text { Wanita }\end{array}$ & $\begin{array}{l}2.9211 \\
3.1435\end{array}$ & -2.742 & $0.007^{* *}$ \\
\hline Harga Premium & $\begin{array}{l}\text { Pria } \\
\text { Wanita }\end{array}$ & $\begin{array}{l}3.5741 \\
3.4179\end{array}$ & 1.661 & $0.098^{*}$ \\
\hline Pengetahuan Ekologikal & $\begin{array}{l}\text { Pria } \\
\text { Wanita }\end{array}$ & $\begin{array}{l}3.4561 \\
3.4298\end{array}$ & 0.448 & 0.655 \\
\hline Kesadaran Lingkungan & $\begin{array}{l}\text { Pria } \\
\text { Wanita }\end{array}$ & $\begin{array}{l}2.3154 \\
2.3324\end{array}$ & -0.453 & 0.651 \\
\hline Niat Beli Hijau & $\begin{array}{l}\text { Pria } \\
\text { Wanita }\end{array}$ & $\begin{array}{l}2.7853 \\
2.7958\end{array}$ & -0.209 & 0.835 \\
\hline Perilaku Beli Hijau & $\begin{array}{l}\text { Pria } \\
\text { Wanita }\end{array}$ & $\begin{array}{l}2.4411 \\
2.3888 \\
\end{array}$ & 0.757 & 0.449 \\
\hline
\end{tabular}

Signifikan ${ }^{* *} p \leq 0.05 * p \leq 0.10$

Hasil Pengujian Perbedaan Gender Pada Variabel Penelitian

Hasil pengujian perbedaan kedua kelompok sampel pria dan wanita menunjukkan bahwa pria lebih memiliki nilai-nilai orientasi individualistik dibandingkan dengan wanita $(p=0.002)$, tetapi baik pria maupun wanita samasama memiliki nilai-nilai orientasi kolektivistik yang relatif tinggi. Konsumen wanita mempunyai kecenderungan emosional terhadap lingkungan daripada konsumen pria ( $p=0.007)$, namun berkaitan dengan produk-produk ramah 
lingkungan, pria lebih memiliki keinginan untuk membayar dengan harga premium daripada wanita. Pengetahuan terhadap lingkungan relatif tinggi untuk konsumen pria maupun wanita, tetapi kesadaran lingkungan, komitmen untuk membeli dan perilaku beli terhadap produk ramah lingkungan relatif sama-sama rendah bagi kedua kelompok konsumen ini.

\subsection{Gender Sebagai Variabel Pemoderasi Dalam Model Persamaan Struktural}

Dalam penentuan strategi pemodelan terdapat tiga jenis model, yaitu confirmatory model, competing model, dan development model. Untuk pengembangan model, teori diperlukan untuk pertimbangan teoritis dalam membentuk dan menentukan hubungan dependen, memodifikasi hubungan yang diusulkan dan menentukan estimasi model (Hair et al., 1998). Teori dalam konteks ini didefinisikan sebagai seperangkat hubungan yang sistematis yang menyediakan penjelasan yang konsisten dan komprehensif terhadap suatu fenomena. Pembentukan model berdasarkan teori memungkinkan memasukkan seluruh variabel dalam satu model yang lengkap. Teori juga menjadi pedoman dalam proses estimasi yang penting ketika memodifikasi suatu model.

Pengujian model dalam penelitian ini menggunakan model konfirmatori, yang terdapat satu model tunggal dan model persamaan struktural digunakan untuk menentukan signifikansi statistiknya. Strategi ini meski sering digunakan, tidak berarti model yang dihasilkan adalah model terbaik. Pada strategi model ini mungkin terjadi bias yang disebut confirmatory bias, yaitu kecenderungan untuk mengkonfirmasi ketepatan model dengan data. Dengan demikian dimungkinkan untuk melakukan modifikasi model. Proses spesifikasi ulang model dapat dilakukan dengan mengasumsikan bahwa semua hubungan diklasifikasikan dalam kategori 1) hubungan teoritis, didasari oleh teori dan tidak dapat dimodifikasi, b) hubungan empiris, hubungan tambahan untuk menyediakan fit bagi model sehingga harus dispesifikasi ulang untuk mendefinisikan nested model teoritis.

Strategi pengembangan model ini dimulai dengan model awal dan melakukan serangkaian spesifikasi ulang atas model tersebut untuk memperbaiki model fit sekaligus menyesuaikan dengan teori dasarnya. Parsimoni model ditentukan oleh kesesuaian setiap koefisien karena absolut fit akan meningkat jika koefisien estimasi ditambah. Perbedaan model ditunjukkan oleh perbedaan nilai chi-square.. Wanita dalam studi tentang kesadaran lingkungan ditemukan wanita lebih terpengaruh daripada pria dalam permasalahan lingkungan karena wanita berdasar peran dan perkembangan sosial lebih mempertimbangkan pengaruh tindakan mereka pada orang lain (Prendengast \& Thompson, 1997; Straughan \& Robert, 1999; Laroche et al., 2001). Namun penelitian Ling-yee (1997) menghasilkan bahwa pria lebih peduli terhadap lingkungan dan lebih aktif terlibat dengan isu-isu dalam masyarakat. Ketidakkonsistenan hasil studi terdahulu menunjukkan bahwa perbedaan gender merupakan pemoderasi hubungan model perilaku konsumen yang berwawasan lingkungan.

Berikutnya untuk pengujian perbedaan gender memoderasi hubungan struktural diantara konstraks penelitian dilakukan dua pengujian model struktural, yaitu model dengan parameter yang terkendala (constrained parameters) dan model dengan parameter yang tidak terkendala (unconstrained parameters). Dalam model dengan parameter yang diberi kendala, bobot estimasi regresi dikendalikan baik untuk sampel pria maupun wanita sehingga memiliki hubungan yang diestimasikan sama. Model dasar ini menghasilkan temuan nilai chi-square $=119.502$ (df=38, p=0.000); GFI= 0.962; AGFI=0.927; RMR= 0.034; RMSEA= 0.055. Sedangkan dalam model alternatif dengan parameter yang dibebaskan menghasilkan temuan chi-square $=96.840$ ( $d f=23, p=0.000$ ); $G F I=$ 0.969; $\mathrm{AGFI}=0.904 ; \mathrm{RMR}=0.025 ; \mathrm{RMSEA}=0.067$. Hasil pengujian model struktural dengan parameter yang diberi kendala secara lebih rinci disajikan pada Tabel 6. 
Tabel 6.

\begin{tabular}{|c|c|c|c|c|}
\hline \multirow[b]{2}{*}{ Structural Relationship } & \multicolumn{2}{|c|}{ Sampel Pria } & \multicolumn{2}{|c|}{ Sampel Wanita } \\
\hline & $\begin{array}{c}\text { Unstandardize } \\
\text { Regression } \\
\text { Weight }\end{array}$ & $\begin{array}{c}\text { Critical } \\
\text { Ratio }\end{array}$ & $\begin{array}{l}\text { Unstandardized } \\
\text { Regression Weight }\end{array}$ & $\begin{array}{c}\text { Critical } \\
\text { Ratio }\end{array}$ \\
\hline $\begin{array}{l}\text { Pengetahuan Ekologikal } \leftarrow \text { Orientasi } \\
\text { Kolektivistik }\end{array}$ & 0.224 & $5.392^{*}$ & 0.224 & $5.392^{*}$ \\
\hline $\begin{array}{l}\text { Pengetahuan Ekologikal } \leftarrow \text { Orientasi } \\
\text { Individualistik }\end{array}$ & 0.236 & $3.607^{*}$ & 0.236 & $3.607^{*}$ \\
\hline $\begin{array}{l}\text { Kesadaran Lingkungan } \leftarrow \text { Pengetahuan } \\
\text { Ekologikal }\end{array}$ & 0.706 & $20.762^{*}$ & 0.706 & $20.762^{*}$ \\
\hline $\begin{array}{l}\text { Kesadaran Lingkungan } \leftarrow \text { Orientasi } \\
\text { Kolektivistik }\end{array}$ & 0.029 & 1.713 & 0.029 & 1.713 \\
\hline $\begin{array}{l}\text { Kesadaran Lingkungan } \leftarrow \text { Orientasi } \\
\text { Individualistik }\end{array}$ & 0.052 & 1.924 & 0.052 & 1.924 \\
\hline $\begin{array}{l}\text { Afek Ekologikal } \leftarrow \text { Pengetahuan } \\
\text { Ekologikal }\end{array}$ & 0.180 & $3.482^{*}$ & 0.180 & $3.482^{*}$ \\
\hline Afek Ekologikal $\leftarrow$ Orientasi Kolektivistik & 0.104 & 1.952 & 0.104 & 1.952 \\
\hline $\begin{array}{l}\text { Afek Ekologikal } \leftarrow \text { Orientasi } \\
\text { Individualistik }\end{array}$ & 0.099 & 1.194 & 0.099 & 1.194 \\
\hline $\begin{array}{l}\text { Harga Premium } \leftarrow \text { Kesadaran } \\
\text { Lingkungan }\end{array}$ & 0.884 & $11.434^{*}$ & 0.884 & $11.434^{*}$ \\
\hline $\begin{array}{l}\text { Harga Premium } \leftarrow \text { Orientasi } \\
\text { Individualistik }\end{array}$ & 0.342 & $4.239^{*}$ & 0.342 & $4.239^{*}$ \\
\hline Niat Beli Hijau $\leftarrow$ Afek Ekologikal & 0.015 & 0.482 & 0.015 & 0.482 \\
\hline $\begin{array}{l}\text { Niat Beli Hijau } \leftarrow \text { Pengetahuan } \\
\text { Ekologikal }\end{array}$ & -1.478 & $-2.174^{*}$ & -1.478 & $-2.174^{*}$ \\
\hline Niat Beli Hijau $\leftarrow$ Kesadaran Lingkungan & 2.944 & $3.062^{*}$ & 2.944 & $3.062^{*}$ \\
\hline Niat Beli Hijau $\leftarrow$ Harga Premium & 0.035 & 0.650 & 0.035 & 0.650 \\
\hline Perilaku Beli Hijau $\leftarrow$ Niat Beli Hijau & 0.775 & $23.223^{*}$ & 0.775 & $23.223^{*}$ \\
\hline \multicolumn{5}{|c|}{ I } \\
\hline Chi Square & \multicolumn{4}{|c|}{119.502} \\
\hline Degree of Freedom & \multicolumn{4}{|c|}{38} \\
\hline Probability & \multicolumn{4}{|c|}{0.000} \\
\hline Chi Square/Degree of Freedom & \multicolumn{4}{|c|}{3.145} \\
\hline GFI & \multicolumn{4}{|c|}{0.962} \\
\hline AGFI & \multicolumn{4}{|c|}{0.927} \\
\hline RMR & \multicolumn{4}{|c|}{0.034} \\
\hline RMSEA & \multicolumn{4}{|c|}{0.055} \\
\hline
\end{tabular}

Hasil Multigroup SEM Gender - Parameter Terkendala

Hasil model persamaan struktural dengan parameter terkendala ini menghasilkan goodness-of-fit yang relatif tinggi dan memenuhi kesesuaian model, yaitu GFI sebesar 0.962 dengan nilai chi square 119.502 dan derajat kebebasan sebesar 38. Temuan penelitian model dengan parameter terkendali ini menjelaskan bahwa baik kelompok konsumen pria maupun wanita, orientasi kolektivistik dan individualistik seseorang mempengaruhi pengetahuan lingkungan konsumen. Semakin tinggi pengetahuan ekologikal seseorang akan meningkatkan kesadaran konsumen terhadap lingkungan sekitarnya. Tingginya pengetahuan ekologikal seorang konsumen 
akan semakin meningkatkan emosi konsumen pada lingkungannya. Namun demikian, baik orientasi individualistik maupun orientasi kolektivistik konsumen tidak berpengaruh pada kesadaran terhadap lingkungan. Seseorang yang memiliki kesadaran lingkungan yang tinggi lebih mau membayar produk-produk ramah lingkungan dengan harga premium dan meningkatkan komitmen konsumen untuk membeli produk pangan organik yang ramah lingkungan.

Kesadaran lingkungan mempengaruhi niat beli konsumen terhadap produk-produk ramah lingkungan dan niat beli hijau ini mempengaruhi perilaku beli konsumen. Dalam penelitian ini ditemukan bahwa pengetahuan seseorang pada lingkungan akan mengurangi niat beli produk ramah lingkungan. Hal ini dapat dijelaskan bahwa seseorang yang memiliki pengetahuan lingkungan yang melebihi orang-orang di sekitarnya akan merasa sensitif terhadap produk-produk berlabel ramah lingkungan dan tidak mudah percaya dengan label yang tertera pada produk hijau tersebut karena konsumen tahu persis tentang proses dan pengolahan pangan organik.

Tabel 7.

\begin{tabular}{|c|c|c|c|c|}
\hline \multirow[b]{2}{*}{ Structural Relationship } & \multicolumn{2}{|c|}{ Sampel Pria } & \multicolumn{2}{|c|}{ Sampel Wanita } \\
\hline & $\begin{array}{l}\text { Unstandardize } \\
\text { Regression } \\
\text { Weight }\end{array}$ & $\begin{array}{l}\text { Critical } \\
\text { Ratio }\end{array}$ & $\begin{array}{l}\text { tandardized } \\
\text { egression } \\
\text { Weight }\end{array}$ & $\begin{array}{c}\text { Critical } \\
\text { Ratio }\end{array}$ \\
\hline $\begin{array}{l}\text { Pengetahuan Ekologikal } \leftarrow \text { Orientasi } \\
\text { Kolektivistik }\end{array}$ & 0.216 & $2.181^{*}$ & 0.206 & $4.449^{*}$ \\
\hline $\begin{array}{l}\text { Pengetahuan Ekologikal } \leftarrow \text { Orientasi } \\
\text { Individualistik }\end{array}$ & 0.531 & $3.263^{*}$ & 0.163 & $2.273^{*}$ \\
\hline $\begin{array}{l}\text { Kesadaran Lingkungan } \leftarrow \text { Pengetahuan } \\
\text { Ekologikal }\end{array}$ & 0.778 & $8.499^{*}$ & 0.694 & $18.771^{*}$ \\
\hline $\begin{array}{l}\text { Kesadaran Lingkungan } \leftarrow \text { Orientasi } \\
\text { Kolektivistik }\end{array}$ & -0.010 & -0.304 & 0.024 & 1.468 \\
\hline $\begin{array}{l}\text { Kesadaran Lingkungan } \leftarrow \text { Orientasi } \\
\text { Individualistik }\end{array}$ & 0.063 & 0.912 & 0.038 & 1.544 \\
\hline $\begin{array}{l}\text { Afek Ekologikal } \leftarrow \text { Pengetahuan } \\
\text { Ekologikal }\end{array}$ & 0.156 & 0.904 & 0.178 & $3.280^{*}$ \\
\hline Afek Ekologikal $\leftarrow$ Orientasi Kolektivistik & 0.034 & 0.207 & 0.105 & 1.855 \\
\hline $\begin{array}{l}\text { Afek Ekologikal } \leftarrow \text { Orientasi } \\
\text { Individualistik }\end{array}$ & 0.395 & 1.361 & 0.068 & 0.778 \\
\hline $\begin{array}{l}\text { Harga Premium } \leftarrow \text { Kesadaran } \\
\text { Lingkungan }\end{array}$ & 0.769 & $4.404^{*}$ & 0.968 & $10.716^{*}$ \\
\hline $\begin{array}{l}\text { Harga Premium } \leftarrow \text { Orientasi } \\
\text { Individualistik }\end{array}$ & 0.292 & 1.525 & 0.369 & $4.135^{*}$ \\
\hline Niat Beli Hijau $\leftarrow$ Afek Ekologikal & 0.054 & 0.950 & -0.005 & -0.130 \\
\hline $\begin{array}{l}\text { Niat Beli Hijau } \leftarrow \text { Pengetahuan } \\
\text { Ekologikal }\end{array}$ & -1.899 & -1.389 & -2.064 & -1.662 \\
\hline Niat Beli Hijau $\leftarrow$ Kesadaran Lingkungan & 3.648 & $2.104^{*}$ & 3.800 & $2.137^{*}$ \\
\hline Niat Beli Hijau $\leftarrow$ Harga Premium & -0.222 & -1.109 & 0.040 & 0.687 \\
\hline Perilaku Beli Hijau $\leftarrow$ Niat Beli Hijau & 0.639 & $8.911^{*}$ & 0.810 & $21.452^{*}$ \\
\hline \multicolumn{5}{|c|}{ Goodness of Fit } \\
\hline Chi Square & \multicolumn{4}{|c|}{96.840} \\
\hline Degree of Freedom & \multicolumn{4}{|c|}{23} \\
\hline Probability & \multicolumn{4}{|c|}{0.000} \\
\hline Chi Square/Degree of Freedom & \multicolumn{4}{|c|}{4.210} \\
\hline GFI & \multicolumn{4}{|c|}{0.969} \\
\hline AGFI & \multicolumn{4}{|c|}{0.904} \\
\hline RMR & \multicolumn{4}{|c|}{0.025} \\
\hline RMSEA & \multicolumn{4}{|c|}{0.067} \\
\hline
\end{tabular}


Hasil Multigroup SEM Gender - Parameter Tidak Terkendala

Model alternatif pada Tabel 7. dengan parameter tidak terkendala memiliki hubungan signifikansi yang berbeda antar-variabel penelitian modelnya. Pengaruh variabel emosional terhadap lingkungan pada pengetahuan lingkungan dalam diri konsumen wanita lebih kuat daripada konsumen pria. Temuan ini mendukung studi yang dilakukan Chan dan Lau (2000) bahwa tingkat emosional seorang wanita terhadap isu-isu lingkungan lebih tinggi dibandingkan dengan pria. Hal ini dapat dijelaskan bahwa tingkat emosional konsumen wanita akan memicu keinginan untuk mengetahui permasalahan-permasalahan yang berkaitan dengan lingkungan. Temuan ini mendukung temuan sebelumnya yang menyatakan bahwa sebagian besar wanita yang membuat keputusan pembelian bahan pangan sehari-hari untuk keluarganya, sehingga konsumen mempunyai hubungan emosional langsung terhadap produk-produk bahan pangan. Orientasi individualistik wanita sebagai seorang pengambil keputusan bahan pangan mempengaruhi keinginan konsumen untuk membayar lebih dengan harga premium untuk produk-produk ramah lingkungan. Hasil ini konsisten dengan penelitian Davies et al. (1995) yang menemukan bahwa konsumen pangan organik adalah wanita yang memiliki anak, mereka lebih dipengaruhi oleh kualitas produk daripada harga dalam membuat keputusan pembeliannya.

Hasil penelitian ini menunjukkan bahwa orientasi kolektivistik dan orientasi individualistik berpengaruh secara signifikan terhadap pengetahuan ekologikal baik konsumen pria maupun wanita pada produk-produk ramah lingkungan. Hasil ini konsisten dengan temuan studi yang dilakukan Ling-yee (1997) dan studi McCarthy dan Shrum (1994) bahwa orientasi kolektivis akan meningkatkan sikap konsumen untuk memahami produk daur ulang. Namun demikian, baik orientasi kolektivistik maupun orientasi individualistik tidak berpengaruh langsung pada kesadaran lingkungan. Menurut Follows dan Jobber (2000), hilai-nilai individualistik seseorang menunjukkan motivasi seseorang pada minat personalnya, tetapi nilai-nilai individualis ini kurang mendukung untuk keramahan lingkungan.

Hasil ini menunjukkan bahwa niat beli konsumen terhadap produk-produk ramah lingkungan tidak ditentukan oleh emosi terhadap lingkungan maupun tingkat pengetahuan konsumen pada lingkungan, namun lebih pada kesadaran konsumen pada lingkungan di sekitarnya. Temuan studi ini menjelaskan bahwa kesadaran lingkungan ternyata berpengaruh secara positif dan signifikan terhadap keinginan membayar dengan harga premium dan niat beli produk ramah lingkungan. Hasil tersebut konsisten dengan studi-studi yang dilakukan sebelumnya (lihat Follows dan Jobber,2000; Laroche et al., 1999; Vlosky et al., 1999; Ling-yee, 1997) bahwa konsumen yang berwawasan lingkungan memiliki perasaan kuat mereka dapat melakukan sesuatu berkaitan dengan ketidakramahan lingkungan dan mencoba mempertimbangkan pengaruh lingkungan sosial dari perilaku pembelian mereka pada suatu produk ramah lingkungan. Selanjutnya, niat beli produk ramah lingkungan berpengaruh positif dan signifikan terhadap perilaku beli produk ramah lingkungan. Sesuai dengan studi Follows dan Jobber (2000) yang mendapatkan niat untuk membeli produk ramah lingkungan merupakan variabel perantara yang mampu menjelaskan hubungan antara kesadaran lingkungan konsumen pada perilaku beli konsumen yang berwawasan lingkungan.

Goodness of fit model dengan parameter tidak terkendala (GFI=0.962) ternyata lebih baik daripada model dengan parameter yang terkendala(GFI=0.969). Selain itu, perbedaan nilai chi square 22.662 dengan derajat kebebasan 15 menunjukkan hasil yang signifikan $(p<0.10)$. Dengan demikian, model dasar dan model alternatif berdasarkan perbedaan gender berbeda secara signifikan. Hal ini mengindikasi bahwa perbedaan gender berpengaruh signifikan sebagai variabel pemoderasi model penelitian ini. Pemoderasian variabel perbedaan gender ini terutama terlihat pada perbedaan hubungan antara pengetahuan ekologikal terhadap afek ekologikal dan antara orientasi nilai individualistik terhadap keinginan membayar harga premium pada konsumen pria dan wanita. Perbandingan antara model dasar dan model alternatif ini dapat ditunjukkan pada Tabel 8. 
Tabel 8.

Perbandingan Goodness of Fit Model Dasar dan

Model Alternatif Gender

\begin{tabular}{|c|c|c|c|}
\hline \multirow{2}{*}{\multicolumn{4}{|c|}{$\begin{array}{l}\text { Perbandingan Goodness of Fit Model Dasar dan } \\
\text { Model Alternatif Gender } \\
\text { Goodness of Fit }\end{array}$}} \\
\hline & & & \\
\hline & $\begin{array}{l}\text { Model Dasar } \\
\text { (Constrained } \\
\text { Parameter) }\end{array}$ & $\begin{array}{c}\text { Model Alternatif } \\
\text { (Unconstrained } \\
\text { Parameter) }\end{array}$ & Criteria \\
\hline Chi Square & 119.502 & 96.840 & \multirow[t]{2}{*}{ Rendah } \\
\hline Degree of Freedom (DF) & 38 & 23 & \\
\hline Probability & 0.000 & 0.000 & $>0.05$ \\
\hline Chi Square/DF & 3.145 & 4.210 & $<5$ \\
\hline GFI & 0.962 & 0.969 & $>0.90$ \\
\hline AGFI & 0.927 & 0.904 & $>0.90$ \\
\hline RMR & 0.034 & 0.025 & $<0.03$ \\
\hline RMSEA & 0.055 & 0.067 & $<0.08$ \\
\hline \multicolumn{4}{|c|}{ Peningkatan Goodness of Fit Model Dasar ke Model Alternatif } \\
\hline $\begin{array}{l}\text { Chi Square } \\
\text { Degree of Freedom (DF) }\end{array}$ & $\begin{array}{r}119.502-9 \\
38\end{array}$ & $\begin{array}{l}40=22,662 \\
=15\end{array}$ & Tinggi \\
\hline Probability & Kuran & ri 0.05 & $<0.05$ \\
\hline Kesimpulan & \multicolumn{3}{|c|}{$\begin{array}{l}\text { Perbedaan } X^{2} \text { sebesar } 22.662 \text { dengan df } 15 \text { lebih } \\
\text { besar dibandingkan dengan } X^{2} \text { tabel }(p<0.10) 22.3072 \\
\text { menunjukkan bahwa model alternatif (Unconstrained } \\
\text { Model) berbeda dengan model dasar (Constrained } \\
\text { Model). Jadi peran gender berpengaruh secara signifikan } \\
\text { sebagai pemoderasi Model Perilaku Konsumen yang } \\
\text { Ramah Lingkungan. }\end{array}$} \\
\hline
\end{tabular}

Ukuran sampel penelitian sejumlah 723 responden ini relatif besar, sehingga hasil mendapatkan probability level yang signifikan baik dalam model persamaan struktural dengan parameter terkendali maupun tidak terkendali. Hal ini mengindikasi adanya perbedaan antara model penelitian dengan data yang diperoleh di lapangan. Jumlah sampel yang disarankan oleh Hair et al. (1998) untuk memenuhi maximum likelihood estimation adalah antara 100200 data dan 200 menjadi jumlah ukuran sampel yang pentng. Jumlah sensitivitas maximum likelihood estimation akan meningkat dalam mendeteksi perbedaan data jika jumlah sampel meningkat, namun apabila jumlah sampel terlalu besar (400-500 data) metode ini menjadi terlalu sensitif dan hampir setiap perbedaan data dideteksi sehingga nilai goodness-of-fit menurun.

Menurut Joreskog dan Sorbom (1988), ukuran yang paling mendasar yang dapat menggambarkan kesesuaian model dengan datanya adalah nilai statistik chi-square. Evaluasi kesesuaian model dengan menggunakan nilai chi-square dapat dilakukan dengan cara membagi nilai chi-square model yang bersangkutan dengan nilai derajat kebebasannya (degree of freedom). Semakin kecil hasil pembagian tersebut (3-5) maka model tersebut semakin sesuai dengan model yang diharapkan.

Berdasarkan hasil perbandingan Goodness of fit model alternatif dan model dasar dapat disimpulkan bahwa hubungan antar-variabel penelitian pada model perilaku konsumen yang bertanggung jawab pada lingkungan dimoderasi oleh perbedaan gender konsumen. Pengembangan model penelitian dengan variabel gender sebagai variabel pemoderasian yang ditawarkan berdasarkan model awal penelitian perilaku konsumen yang berwawasan lingkungan ini supaya dapat lebih jelas dapat dilihat pada Gambar 3. 


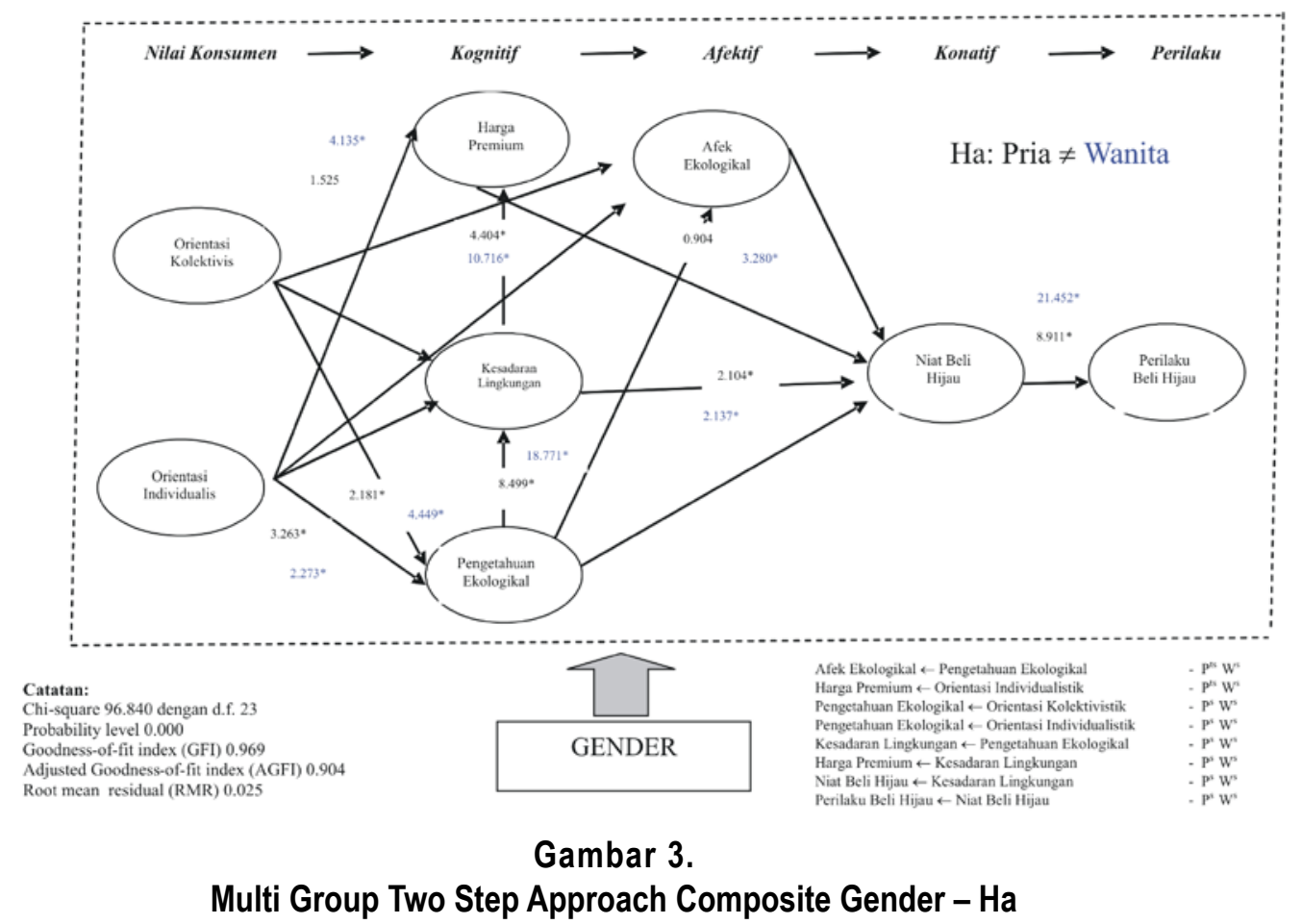

\section{SIMPULAN}

Hubungan antar-variabel model persamaan struktural penelitian ini baik konsumen pria maupun wanita memiliki kesamaan, kecuali pada konsumen wanita orientasi nilai individualistik berpengaruh pada keinginan untuk membayar pangan organik dengan harga premium. Temuan ini mendukung hasil penelitian sebelumnya yang menyebutkan bahwa konsumen yang selalu mencari produk pangan organik secara aktif kebanyakan adalah wanita yang memiliki anak, mereka lebih dipengaruhi oleh kualitas produk daripada harga dalam membuat keputusan pembelian. Para konsumen wanita ini memiliki nilai-nilai yang berorientasi pada kemakmuran, citra diri, kesuksesan, kemampuan, kecerdasan, kenikmatan hidup, tantangan hidup dan pilihan tujuan hidup yang mempengaruhi rendahnya sensitivitas terhadap produk-produk yang ramah lingkungan.

Kesadaran lingkungan seorang konsumen akan mempengaruhi keinginannya untuk membeli produk ramah lingkungan dengan harga premium dan meningkatkan komitmen konsumen untuk bersikap dan berperilaku ramah lingkungan. Jadi seseorang yang sadar untuk tetap selalu menjaga tanggung jawab lingkungan ternyata akan meningkatkan komitmen konsumen untuk mengaktualisasikan pembelian konsumen pada produk-produk yang ramah lingkungan. Temuan ini sangat menarik untuk didalami lebih lanjut apa sebenarnya yang menyebabkan niat beli seorang konsumen untuk menunjang tanggung jawab pada lingkungan sekitarnya kecuali dipengaruhi kesadaran terhadap lingkungan.

\section{DAFTAR PUSTAKA}

Ajzen,Icek., (1988), Attitudes, personality, and Behavior, Open University Press, Milton Keynes, UK.

Ajzen, I. \& M. Fishbein, (1980), Understanding Attitudes and Predicting Social Behavior, Prentice Hall, Englewood Cliffs, NJ.

Anonim, (2005), "Produk Organik Tak Harus Mahal", Kompas, Minggu, 8 Mei 2005, hal. 40.

Bender, M. \& B. Derby (1992), "Prevalence of Reading Nutrition and Ingredient Information on Food Labels: 1982- 
1988," Journal of Nutrition Education, Vol. 24, No. 6, pp. 292-297.

Bloom, David E. \& Jaypee Sevilla, (2004), "Willingness to Pay for Environmental Quality: Testable Empirical Implications of the Growth and Environment Literature: Comment", Journal in Economic Analysis \& Policy, Vol 3, Iss. 1.

Chan, T.S., (1996), "Concerns for Environmental Issues and Consumer Purchase Preferences: A Two-Country Study," Journal of International Consumer Marketing, 9:1, pp. 43-55.

Chan, Ricky Y.K., (1999), "Environmental Attitudes and Behavior of Consumers in China: Survey Findings and Implications," Journal of International Consumer Marketing, 11:4, pp. 25-52.

Chan, Ricky Y.K.\& Lorett B. Y. Lau (2000), "Antecedents of Green Purchases: A Survey in China," Journal of Consumer Marketing, Vol. 17 No. 4, pp.338-357.

Chan, Ricky Y.K. (2001), "Determinants of Chinese Consumers' Green Purchase Behavior," Psychology \& Marketing, Vol. 8, No. 4, April, pp. 389-413.

Cooper, D.R. \& Emory, C.W. (1995), Business Research Methods, Fifth Edition, Chicago: Richard D. Irwin, Inc.

Cooper, D.R. \& Schindler (2001), Business Research Methods, Seventh Edition, McGraw-Hill International..

Davies, Anne, Albert J. Titterington \& Clive Cochrane, (1995), "Who Buys Organic Food? A Profile of the Purchasers of Organic Food in Northern Ireland," British Food Journal, Vol. 97 No. 10, pp. 17-23.

Follows, Scott B. \& David Jobber, (2000), "Environmentally responsible purchase behaviour: a test of a consumer model," European Journal of Marketing, Vol. 34, №. 5/6, pp.723-746.

Fotopoulos, Christos \& Athanasios Krystallis, (2002), "Purchasing motives and profile of the Greek organic consumer: a countrywide survey," British Food Journal, Vol. 104, No. 9, pp.730-765.

Hair, Joseph F., Rolph E. Anderson, Ronald L. Tatham, \& William C. Black (1998), Multivariate Data Analysis, Fifth Edition, Prentice Hall International, Inc.

Haley, Russell I. (1995), "Benefit Segmentation: A Dcision-Oriented Research Toll," dalam Marketing Classics, Prentice Hall Inc.

Ippolito, P. M. \& A.D. Mathios (1991), "Health Claims in Food Marketing:Evidence on Knowledge and Behavior in the Cereal Market," Journal of Public Policy \& Marketing, Vol. 10, Spring, pp. 15-32.

Jiuan, T.S., Jochen Wirtz, Kwon Jung \& Kau Ah Keng (2001), "Singaporeans' Attitudes towards work, pecuniary adherence, materialism, feminism, environmental consciousness, and media credibility", Singapore Management Review, 23, 1, pp. 59-86.

Johri, Lalit M. Johri, Kanokthip Sahasakmontri (1998) "Green Marketing of cosmetics and toiletries in Thailand", The Journal of Consumer Marketing, Vol. 15 No. 3, pp. 265-281.

Junaedi, Shellyana (2003), "Analisis Faktor Demografi, Akses Media dan Sumber Informasi Terhadap Kepedulian dan Kesadaran Lingkungan Konsumen: Kajian Pemasaran yang Berwawasan Sosial," Kinerja Jurnal Bisnis dan Ekonomi, Vol. 7 No. 2, hal. 24-39.

Junaedi, Shellyana (2005), "Pengaruh Kesadaran Lingkungan pada Niat Beli Produk Hijau: Studi Perilaku Konsumen Berwawasan Lingkungan," Benefit Jurnal Manajemen dan Bisnis, Vol. 9, No. 2, hal. 189-201. 
Junaedi, Shellyana (2006), "Pengembangan Model Perilaku Konsumen Berwawasan Lingkungan di Indonesia: Studi Perbandingan Kota Metropolitan dan Non Metropolitan," Jurnal Ekonomi \& Bisnis Indonesia, Vol 21 No.4, Oktober, hal 399-419.

Kalafatis, Stavros P., Michael Pollard, Robert East, \& Markos H. Tsogas (1999), "Green Marketing and Ajzen's Theory of Planned Behaviour: A Cross-market Examination," Journal of Consumer Marketing, Vol. 16 No. 5, pp.441-460.

Konsky, C., J. Blue, M. Eguchi \& S. Kapoor (2002), "Individualist Collectivist Values-American, Indian and Japanese Cross Cultural Study".

Laroche, Michel, Jasmin Bergeron, \& Guido Barbaro-Forleo (2001), "Targeting Consumers Who are Willing to Pay More for Environmentally Friendly Products," Journal of Consumer Marketing, Vol. 18, No. 6, pp. 503520 .

Ling-yee, Li, (1997), "Effect of collectivist orientation and ecological attitude on actual environmental commitment: The moderating role of consumer demographics and product involvement," Journal of International Consumer Marketing, Vol. 9 No. 4, pp. 31-53.

Martin, Bridget \& Antonis C. Simintiras, (1995), "The impact of green product lines on the environment: does what they know affect how they fell?", Marketing Intelligence \& Planning Vol. 13 No. 4, pp. 16-23.

Mathios, A.D. (1996), "Socioeconomic Factors, Nutrition, and Food Choices: An Analysis of the Salad Dressing Market," Journal of Public Policy \& Marketing, Vol. 15, No.1, Spring, pp 45-54.

McCarty, J.A. \& Shrum, L.J. (1994), "The recycling of solid wastes: personal values, value orientation, and attitudes about recycling as antecedents of recycling behavior", Journal of Business Research, Vol. 30, No. 1, pp. 53-62.

Mueller, Ralph O. (1996), Bacis Principles of Structural Equation Modeling: An Introduction to LISREL and EQS, Springer.

Neuman, W. Lawrence (2000), Social Research Methods: Qualitative and Quantitative Approaches, Fourth Edition, Allyn and Bacon.

Ottman, J.A. (1994), Green Marketing: Challenges and Opportunities for the New Marketing Age, NTC Publishing Group, Lincolwood.

Prendergast, Gerard P. \& Edmund R. Thompson, (1997), "Cynical segmentation of environmental markets: The Product of marketers' dispositions or corporate demands?" Journal of Euro Marketing, Vol. 6 No. 4, pp. 17-34.

Purwanto, B.M. (2000), "Pelatihan Pengukuran dan Teknik Statistik Untuk Riset Keperilakuan", Yogyakarta, 31 Agustus-1 September.

Purwanto, B.M. (2004), "Does Gender Moderate the Effect of Role Stress on Salesperson's Internal State and Performance? An Application of Multigroup Structural Equation Modeling (MSEM)", Buleting Ekonomi: Jurnal Manajemen, Akuntansi dan Ekonomi Pembangunan, Vol. 6, August.

Samdahl, D.M. \& R. Robertson (1989), "Social determinants of environmental concern: specification and test of the model", Environment and Behavior, Vol. 21, No. 1, pp. 57-81. 